\title{
Physiological gut oxygenation alters GLP-1 secretion from the enteroendocrine cell line STC-1
}

\author{
Alina Kondrashina ${ }^{1}$, Dmitri Papkovsky ${ }^{2}$, Linda Giblin ${ }^{1}$ \\ ${ }^{1}$ Food for Health Ireland, Teagasc Food Research Centre, Moorepark, Fermoy, Co.Cork, Ireland \\ ${ }^{2}$ School of Biochemistry and Cell Biology, University College Cork, Cork, Ireland.
}

Correspondence: Dr. Linda Giblin

Teagasc Food Research Centre, Moorepark, Fermoy, Co.Cork, Ireland, Tel. +3532542614.

(linda.giblin@teagasc.ie)

\begin{abstract}
Abbreviations:
AEBSF, 4-(2-aminoethyl)benzenesulfonyl fluoride hydrochloride; cAMP, cyclic adenosine monophosphate; CCK, cholecystokinin; DPP-IV, dipeptidyl peptidase IV; FA, fatty acids; Fsk, forskolin; GI tract, gastro-intestinal tract; GLP-1, glucagon-like-peptide-1; GPCR, G-protein coupled receptor; HIF-1 $\alpha$, hypoxia inducible factor $1 \alpha$; IBMX, 1-mathyl-3-(2-mathylpropyl)-7Hpurine-2,6-dione; MW-SPPS, microwave-assisted solid phase peptide synthesis; PYY, peptide YY; ROS, reactive oxygen species; RP-HPLC, Reversed phase HPLC; SGF, simulated gastric fluid; SIF, simulated intestinal fluid; SSF, simulated salivary fluid; VAS, visual analogue scale.
\end{abstract}

Keywords: Glucagon-Like Peptide-1, intestinal nutrient sensing, physiological gut oxygenation, satiety hormones, simulated digestion.

Received: 05-Jul-2017; Revised: 05-Sep-2017; Accepted: 13-Sep-2017

This article has been accepted for publication and undergone full peer review but has not been through the copyediting, typesetting, pagination and proofreading process, which may lead to differences between this version and the Version of Record. Please cite this article as doi: 10.1002/mnfr.201700568.

This article is protected by copyright. All rights reserved. 


\section{Abstract}

Scope: Enteroendocrine cell lines are routinely assayed in simple buffers at $\sim 20 \%$ oxygen to screen foods for bioactives that boost satiety hormone levels. However, in vivo, enteroendocrine cells are exposed to different phases of food digestion and function at low oxygen concentration ranging from $7.5 \%$ in the stomach to $0.5 \%$ in the colon-rectal junction.

Methods and results: The objective of this study was to investigate the effect of physiologically relevant $\mathrm{O}_{2}$ concentrations of the gut on the production and secretion of the satiety hormone, GLP-1, from the murine enteroendocrine cell line, STC-1, in response to dairy macronutrients as they transit the gut. GLP-1 exocytosis from STC-1 cells is influenced by both oxygen concentration and by individual macronutrients. At low oxygen STC-1 cell viability was significantly improved for all macronutrient stimulations and cAMP levels were dampened. GLP-1 secretion from STC-1 cells was influenced by both the phase of yogurt digestion and corresponding $\mathrm{O}_{2}$ concentration. Atmospheric oxygen at $4.5 \%$ combined with upper gastric digesta, which simulates ileum conditions, yields the highest GLP-1 response.

Conclusion: This demonstrates the importance of considering physiological oxygen levels and food digestion along GI tract for reliable in vitro analysis of gut hormone secretion.

\section{Introduction}

Healthy foods that increase feeling of fullness may reduce food intake and therefore help to manage weight over time. As such there has been considerable scientific interest in screening for food bioactives that modulate satiety signals in the gut. To be physiologically relevant, such in vitro screening platforms must closely resemble in vivo conditions.

Specialised endocrine L cells in the gastro-intestinal (GI) tract respond to food ingestion by secreting a range of satiety hormones, including Glucagon-like peptide-1 (GLP-1), cholecystokinin (CCK) and peptide YY (PYY) [1, 2]. GLP-1 has effects on the ileal brake, gastric emptying, the hypothalamic circuits that regulate food intake and insulin secretion via its receptor GLP-1R. Secretion of GLP-1 in the GI tract occurs via elevation of cAMP and/or cytoplasmic $\mathrm{Ca}^{2+}$ concentrations, with both of these 
signalling pathways highly influenced by macronutrients in contact with L-cells $[3,4]$. Some studies show that carbohydrates are the main stimulants of GLP-1 secretion, whereas other studies favour proteins $[5,6]$. Fatty acids (FA) also play an important role in GLP-1 release via the G-coupled protein receptors GPR40 and GPR120 [7, 8]. To date in vitro studies of GLP-1 production, secretion and the underlying mechanisms involved have been focused on individual ingredients and macronutrients rather than whole foods or digesta [9].

Enteroendocrine open type L cells are found throughout the length of the GI tract, with their numbers increasing towards the distal gut $[10,11]$. As such, these cells are exposed to the lumen contents, from whole foods to digesta and to varying $\mathrm{O}_{2}$ concentrations. $\mathrm{O}_{2}$ level drops from $10-7.5 \%$ in the stomach to $1.5-0.5 \%$ in the colon-rectal junction $[12,13]$. Together with nutrient content of the food, stage of food digestion and pathological conditions, $\mathrm{O}_{2}$ tension most likely plays a significant role in GLP-1 production and secretion [14]. Physiological normoxia $\left(2-5 \% \mathrm{O}_{2}\right.$ in cellular environment) has attracted significant attention recently, as it affects many aspects of cell activities including secretory function as metabolism switches from oxidative phosphorylation to anaerobic glycolysis with subsequent increase in glucose consumption [15-17]. Cell adaptation to the low $\mathrm{O}_{2}$ is mediated by hypoxia inducible factor 1 (HIF-1). Its $\alpha$ subunit is rapidly degraded at normoxia, however at lower $\mathrm{O}_{2}$ it stabilises and regulates expression of genes, involved in cellular response [18]. Recently there is evidence that hypoxia decreases levels of proglucagon mRNA transcript and secreted GLP-1 in GLUTag cells exposed to glucose and the cAMP stimulator forskolin (Fsk) [19].

The murine and human L cell lines STC-1, GLUTag, NCI-H716, are popular models for studying gut hormone expression and secretion in response to food components [20-22]. However differences do exist with native L cells $[23,24]$. These cell lines are routinely tested with intact individual macronutrients as well as monosaccharides, amino acids and fatty acids, at ambient $\mathrm{O}_{2}(\sim 20 \%$ in air), and not with food digesta at physiologically relevant $\mathrm{O}_{2}$ concentrations.

The objective of this study was to investigate the effect of physiologically relevant $\mathrm{O}_{2}$ concentrations (i.e. atmospheric hypoxia) on the production and secretion of GLP-1 from the murine enteroendocrine cell line, STC-1, in the presence of dairy components as they transit the GI tract. In epidemiological 
and intervention studies consumption of dairy products has been associated with short and long term satiety [25] and has demonstrated positive effects on appetite suppression, energy intake and body weight $[26,27]$. Fermented dairy beverages and yogurts have the highest satiety by visual analogue scales (VAS) and/or by ad libitum energy intake $[28,29]$. There is evidence that the satiety effect of individual milk ingredients is mediated via secretion of GLP-1 [30]. For instance the major milk protein component, casein, bolsters GLP-1 secretion in vitro [31, 32] and in vivo [33]. Oleic and butyric acids, which represents $23.8 \%$ and $4.4 \% \mathrm{w} / \mathrm{w}$ of the total fatty acids in milk, increase GLP-1 exocytosis from the GLUTag cell line and from primary murine L cells [7, 34, 35]. Possible effects of milk disaccharide, lactose, on GLP-1 release have not been investigated but digestion of lactose releases galactose and glucose, which are effective secretory stimulants of GLP-1 [3, 36].

We hypothesised that $\mathrm{O}_{2}$ availability and hypoxia signalling pathways will impact on GLP-1 exocytosis in response to food, using enteroendocrine cells and dairy macronutrients as in vitro model system.

\section{Materials and Methods}

\subsection{Materials}

Krebs-Ringer buffer was sourced from Sigma Aldrich (Ireland). 100X Halt Protease and Phosphatase Inhibitor was purchased from Thermo Fisher Scientific (MSC, Ireland). 10X Gel Prep/Running buffer was sourced from Ambion (Applied Biosystems, USA). Mouse Metabolic Magnetic Bead Panel for active GLP-1 (\#MMHMAG-44K) was from Millipore (Ireland). RNeasy RNA extraction kit, oncolumn DNase digestion kit and cell lysis buffer were from Qiagen (UK). Tetro cDNA synthesis kit was from Bioline (MSC, Ireland). LightCycler 480 SYBR Green I Master mix for tPCR was from Roche (Roche Products Ireland Limited). CellTitter One solution reagent and CellTox Green viability assay kit were from Promega (MyBIO, Ireland). Fluo-4 AM calcium indicator was from Molecular probes (UK). Direct cAMP ELISA kit and forskolin were from Enzo Life Sciences (UK). STC-1 was purchased from the American Tissue Culture Collection (ATCC code SD5482, supplied by LGC Standards, Teddington, UK). Casein (sodium caseinate from bovine milk, 95.6\% protein on dry 
matter) was from Arrabawn (Ireland). Low fat Greek style natural yogurt $(2.8 \mathrm{~g}$ fat, $5.6 \mathrm{~g}$ carbohydrates, $5.2 \mathrm{~g}$ protein per $100 \mathrm{~g}$ ) was sourced from Tesco, Ireland. Oligonucleotide primers were synthesized by IDT (Belgium). LRF tripeptide was synthesised by microwave-assisted solid phase peptide synthesis (MW-SPPS) and purified using RP-HPLC. All other reagents were from Sigma Aldrich (Ireland). Filter-tubes with threshold $10 \mathrm{kDa}$ were from Satorius (Ireland). Other plastic ware was from Sarstedt (Ireland).

\subsection{Cell culture}

Murine intestinal neuroendocrine tumour cell line STC-1 was cultured in Dulbecco's Modified Eagle Medium (DMEM) containing $4.5 \mathrm{~g} / \mathrm{L}$ of glucose and L-glutamine, supplemented with $10 \%$ Foetal Bovine Serum (FBS), $100 \mathrm{U} / \mathrm{mL}$ penicillin and $100 \mu \mathrm{g} / \mathrm{mL}$ streptomycin. Cells (between passage numbers 25-33) were grown at $37^{\circ} \mathrm{C}$ and $5 \% \mathrm{CO}_{2}$ up to a confluence $80-90 \%$, media was changed every 2 days and cells were passaged every 2-3 days.

\subsection{STC-1 cell exposure}

STC-1 cells were seeded in 6 well plates at concentration $1.5 \times 10^{6}$ cells/well in standard growth media and incubated for 18 hours at $37^{\circ} \mathrm{C}, 5 \% \mathrm{CO}_{2}$. For cell viability, cytotoxicity and intracellular $\mathrm{Ca}^{2+}$ assays, STC-1 cells were seeded at a concentration of $0.1 \times 10^{6}$ cells $/ \mathrm{mL}$ in 96 well plates. For cAMP accumulation assay, $0.5 \times 10^{6}$ cell/well were seeded in 24 well plates. The following day, media was aspirated and cells were washed once with modified Krebs-Ringer buffer (without bicarbonate but with $10 \mathrm{mM}$ HEPES) and then pre-incubated in the same buffer for 1 hour to acclimatise. Buffer was then aspirated and replaced with $1 \mathrm{~mL}(0.1 \mathrm{~mL}$ for 96 well plate) of macronutrients $(100 \mu \mathrm{M}$ oleic acid, $100 \mu \mathrm{M}$ butyric acid, $0.5 \mathrm{mg} / \mathrm{mL}$ tripeptide $\mathrm{LRF}, 10 \mathrm{mg} / \mathrm{mL}$ casein, $40 \mathrm{mM}$ glucose, $40 \mathrm{mM}$ lactose) prepared in modified Krebs-Ringer buffer. Yogurt and yogurt digesta were diluted in the modified Krebs-Ringer buffer for a final concentration of $10 \mathrm{mg} / \mathrm{mL}$. Phenol red free DMEM, supplemented with 10 mM HEPES was used as a control for cell viability assays. For cAMP accumulation assays, modified Krebs-Ringer buffer was supplemented with $1 \mathrm{mM}$ 
3-Isobutyl-1-methylxanthine (IBMX); and $10 \mu \mathrm{M}$ Fsk was used as a positive control. All non-sterile solutions were filter-sterilised $(0.45 \mu \mathrm{m})$ prior to cell exposures for 4 hours at $37^{\circ} \mathrm{C}$.

\subsection{Hypoxic and normoxic conditions}

For the experiments at ambient $(\sim 20 \%) \mathrm{O}_{2}$, standard $37^{\circ} \mathrm{C}$ incubator was used without $\mathrm{CO}_{2}$ supply. For experiments under hypoxic atmosphere, cells were placed in a flushing hypoxia chamber (Billups-Rothenberg, Inc., USA), equilibrated at $0.5-7.5 \% \mathrm{O}_{2}$ (verified by Optech ${ }^{\circledR}$ Platinum $\mathrm{O}_{2}$ sensor, Mocon, USA) and inserted in a $37^{\circ} \mathrm{C}$ incubator [37].

\subsection{GLP-1 (active) secretion}

Following the incubation period, $10 \mu \mathrm{L}$ of $100 \mathrm{X}$ Halt Protease and Phosphatase Inhibitor were used to inactivate endogenous DPP-IV activity, cell supernatants were collected to $1.5 \mathrm{~mL}$ tubes and centrifuged at $900 \mathrm{~g}$ and $4^{\circ} \mathrm{C}$ for $5 \mathrm{~min}$ to remove cellular debris. Supernatants were stored at $-80^{\circ} \mathrm{C}$ prior to quantification of GLP-1 (active) levels. This was performed with Milliplex Map Kit and MagPix fluorescent detection system according to the manufacturer's instructions. Milliplex assay allows detection of active GLP-1 in the range 41-30000 pg/mL, by using 5-parameter logistic curve fitting method and quantifying of samples according to the standard curve.

\subsection{RNA extraction and real-time PCR}

After 4 hours exposure to macronutrients, STC-1 cell monolayers were washed once with PBS buffer, pelleted, re-suspended in $0.35 \mathrm{~mL}$ of lysis buffer and stored at $-80^{\circ} \mathrm{C}$ prior to RNA extraction. RNA extraction was performed with RNeasy Mini Kit, including on-column DNase digestion, following the manufacturer's instructions. Total RNA was quantified spectrophotometrically, using the Nanodrop 1000 (Thermo Fisher Scientific, USA). RNA integrity was assessed by electrophoresis (BioRad, USA) in a $1.5 \%$ glyoxyl agarose gel and glyoxyl buffer. Tetro cDNA synthesis kit was used to prepare cDNA from $1 \mu \mathrm{g}$ of RNA according to the manufacturer's instructions. Real time PCR was performed with a Light Cycler 96 instrument (Roche Diagnostics, Germany) and LightCycler 480 
SYBR Green I Master kit to quantify proglucagon, PYY, CCK and HIFla mRNA levels. All primers were designed across intron-exon boundaries. Primers for murine proglucagon (Z46845.1): forward CCTTCAAGACACAGAGGAGAAC; reverse GGAGTCGAGGTATTTGCTGTAG， annealing temperature $56^{\circ} \mathrm{C}$. Primers for murine CCK (NM_001284508): forward CTGTCTGCATTTGGCTTGAC; reverse GCCCACTACGATGGGTATTC, annealing temperature 55 $5^{\circ}$. Primers for murine PYY (NM_145435.1): forward AACTGCTCTTCACAGACGAC; reverse GTGCCCTCTTCTTAAACCAAAC, annealing temperature $55^{\circ} \mathrm{C}$. Primers for murine $A c t B$ (NM_007393.5): $\quad$ forward $\quad$ TGTGACGTTGACATCCGTAAAG; $\quad$ reverse TCAGTAACAGTCCGCCTAGAA, annealing temperature $51^{\circ} \mathrm{C}$. Primers for murine HIFla (NM_001313919.1): forward CCCATTCCTCATCCGTCAAATA, reverse CCTGTGGTGACTTGTCCTTTAG, annealing temperature $55^{\circ} \mathrm{C}$. Efficiency of amplification was measured by performing PCR for 4 dilutions of cDNA $(1: 1,1: 10,1: 100,1: 1000)$ and was in the range of 1.87-2.15. For each PCR reaction $8 \mu \mathrm{L}$ of pre-mix were mixed with $0.5 \mu \mathrm{L}$ of each forward or reverse primer and $1 \mu \mathrm{L}$ of cDNA. Inter-assay and intra-assay variation was less than $5 \%$. For each sample, the relative amount of target was calculated by the $2^{-\Delta \Delta C}{ }_{T}$ method, where $\Delta \Delta C_{T}=\left(C_{T}\right.$, Target $\left.\mathrm{C}_{\mathrm{T}, \text { Actin }}\right)_{\mathrm{x}}-\left(\mathrm{C}_{\mathrm{T}, \text { Target }}-\mathrm{C}_{\mathrm{T}, \text { Actin }}\right)_{0}$, where 0 corresponds to the control conditions and $\mathrm{x}$ - to experimental conditions.

\subsection{Cell viability and cytotoxicity assays}

After 2 hours of cell exposure, $20 \mu \mathrm{L}$ of Cell Titter One solution were added to wells, and STC-1 cells were incubated for another 2 hours. Absorbance at $490 \mathrm{~nm}$ in each well was recorded with Synergy plate reader (BioTek, USA) and viability was calculated as percentage of positive control, which was measured in supplemented with $10 \mathrm{mM}$ HEPES DMEM at $20 \% \mathrm{O}_{2}$. For cytotoxicity assay, CellTox ${ }^{\mathrm{TM}}$ Green compound was added directly to the cell exposure solution (1:500 dilution in $50 \mu \mathrm{L}$ per well) and fluorescence signal (ex. $485 \mathrm{~nm}$, em. $520 \mathrm{~nm}$ ) was measured after 4 hours of incubation. Cell lysate was used as the positive control and assigned a value of $100 \%$ cytotoxicity. 


\section{8 cAMP accumulation assay}

Intracellular cAMP levels were measured using a Direct cAMP ELISA kit, according to manufacturers' instructions. After cell exposure to control or $10 \mathrm{mg} / \mathrm{mL}$ casein supernatant was removed and cells were lysed with $0.2 \mathrm{~mL}$ of $0.1 \mathrm{M} \mathrm{HCl}$ for 10 minutes at room temperature. Cellular debris was removed by centrifugation at $900 \mathrm{~g}$ for 5 minutes and samples were stored at $-80^{\circ} \mathrm{C}$ prior to analysis. Results were generated at optical density of $405 \mathrm{~nm}$ using a Synergy plate reader. This ELISA kit allows detection of cAMP with sensitivity $0.39 \mathrm{pmol} / \mathrm{mL}$, using standard curve for the range $0.78-200 \mathrm{pmol} / \mathrm{mL}$.

\subsection{Intracellular $\mathrm{Ca}^{2+}$ assay}

After 3 hours exposure to control or $10 \mathrm{mg} / \mathrm{mL}$ casein in physiological normoxic/hypoxic conditions, cells were loaded with $2.5 \mu$ M Fluo-4 AM intracellular $\mathrm{Ca}^{2+}$ probe and incubation was continued for another 1 hour. Following this period, cell monolayers were washed 2 times with Krebs-Ringer buffer supplemented with $0.1 \mathrm{mM}$ sulfinpyrazone, to prevent changes in intracellular $\mathrm{Ca}^{2+}$ levels and leakage of de-esterified indicator. Fluorescent signals of intracellular Fluo-4 AM probe were collected with Synergy plate reader, using excitation $488 \mathrm{~nm}$ and emission $520 \mathrm{~nm}$.

\subsection{Simulated gastro-intestinal digestion (SGID)}

SGID of yogurt sample was performed based on the detailed protocol by Minekus et.al. [44]. In short, $2 \mathrm{~g}$ of yogurt were mixed with simulated salivary fluid (SSF, $1.25 \mathrm{x}$ concentrate), $\mathrm{H}_{2} \mathrm{O}, \mathrm{CaCl}_{2}$ and human salivary $\alpha$-amylase for a final activity of $75 \mathrm{U} / \mathrm{mL}$. The sample was mixed for $>2$ min at $37^{\circ} \mathrm{C}$ to mimic oral phase. Half of the volume was removed and inactivated (amylase activity) by reducing $\mathrm{pH}$ to 3 and re-adjusting to 7 . Remaining bolus was mixed with simulated gastric fluid (SGF, 1.25x concentrate) for the final ratio $50: 50 \mathrm{v} / \mathrm{v}, \mathrm{CaCl}_{2}$ and porcine pepsin $(2000 \mathrm{U} / \mathrm{mL}$ in the final mixture). The $\mathrm{pH}$ was reduced to 3 and water was added to dilute SGF. The mixture was incubated for 2 hours at $37^{\circ} \mathrm{C}$ on rotor shaker to simulate gastric movement. Pepsin was inactivated in half of the volume by re-adjusting $\mathrm{pH}$ to 7 . Remaining gastric chime was mixed with simulated intestinal fluid (SIF, 1.25x 
concentrate) for the final ratio $50: 50 \mathrm{v} / \mathrm{v}$ and neutralised to $\mathrm{pH}$ 7. Pancreatin was added according to its trypsin activity $(100 \mathrm{U} / \mathrm{mL}$ in the final mixture). Bile salts were added to the final concentration $10 \mathrm{mM}, \mathrm{CaCl}_{2}$ was then added to reach $0.3 \mathrm{mM}$ in the final mixture and $\mathrm{pH}$ was re-adjusted with $1 \mathrm{M}$ $\mathrm{NaOH}$. SIF was diluted with $\mathrm{H}_{2} \mathrm{O}$ and digestion was performed for 2 hours at $37^{\circ} \mathrm{C}$ on rotor mixer. Pancreatic activity was stopped by $2.4 \mathrm{mg}$ of AEBSF (4-(2-aminoethyl) benzenesulfonyl fluoride hydrochloride) per $10 \mathrm{~mL}$ of digesta. Digesta was then diluted with distilled $\mathrm{H}_{2} \mathrm{O}$ at a ratio of 1:5. Trypsin was removed by filtration with centrifuge tube concentrator (molecular weight cut-off $10000 \mathrm{Da}$ at $5000 \mathrm{~g}, 10 \mathrm{~min}, 4^{\circ} \mathrm{C}$ ). Aliquots of digesta after each phase (oral, gastric and intestinal) were immediately snap-frozen in liquid nitrogen for $30 \mathrm{sec}$ and stored at $-80^{\circ} \mathrm{C}$ prior to $\mathrm{STC}-1$ cell exposures.

\subsection{Data assessment and statistics}

Cell viability, cytotoxicity and intracellular $\mathrm{Ca}^{2+}$ data were obtained from 2 experimental repeats on different days and 3 technical repeats within each experiment. Active GLP-1, cAMP and PCR data were obtained from at least 2 experimental repeats on different days and 2 technical repeats within each experiment. Data is presented as means with SD as error bars. Statistical analysis was performed by Paired-samples t-test or One-Way analysis of variance (ANOVA) in PASW statistics 18 software. Means without a common letter differ significantly from each other $(\mathrm{P}<0.05)$.

\section{Results and Discussion}

3.1 Low $\mathrm{O}_{2}$ conditions decrease GLP-1 secretion from STC-1 cells

To determine how GLP-1 secretion in response to individual dairy macronutrients is influenced by hypoxic conditions $\left(0.5 \% \mathrm{O}_{2}\right.$ in the atmosphere) protein (casein), carbohydrate (lactose) and fat (oleic acid) components of milk were selected. In vivo transit of food through the length of the GI tract is accompanied not only by changes in $\mathrm{O}_{2}$ tension, but also results in the digestion of food and appearance of macronutrient breakdown products. To mimic the typical food components that $\mathrm{L}$ cells, located in the distal gut, would be exposed to, a sodium caseinate tripeptide LRF, glucose (the 
breakdown product of lactose) and butryic acid (a short chain fatty acid which is found in milk but also produced by gut bacteria [38]) were also selected. The final concentrations for the food components were as previously described: $10 \mathrm{mg} / \mathrm{mL}$ casein, $40 \mathrm{mM}$ lactose, $100 \mu \mathrm{M}$ oleic acid, 0.5 $\mathrm{mg} / \mathrm{mL}$ tripeptide LRF, $40 \mathrm{mM}$ glucose and $100 \mu \mathrm{M}$ butyric acid [39-42]. Macronutrients were prepared in modified Krebs Ringer buffer with buffering system based on $10 \mathrm{mM}$ HEPES and without bicarbonate to maintain the required $\mathrm{pH}$ of 7.2-7.4 in the sealed flushing hypoxia chamber without $\mathrm{CO}_{2}$ supply [37]. Hypoxic conditions were reached, as determined by a significant fold increases in HIFla mRNA transcript levels compared to ambient air conditions for all macronutrient exposures (data not shown). Low $\mathrm{O}_{2}$ significantly decreased $(\mathrm{P}<0.05)$ levels of active GLP-1 secreted from STC1 cells in response to glucose, oleic acid, tripeptide and casein compared to ambient $\mathrm{O}_{2}$ (Fig.1A). None of the nutrients tested, except intact casein, were capable of stimulating GLP-1 above levels observed for $11 \mathrm{mM}$ glucose (modified Krebs-Ringer buffer control). This concentration of glucose is necessary for cell viability, however it may mask the stimulatory effects of other macronutrients. GLP-1 production, as measured by proglucagon mRNA transcript levels, was unaffected by hypoxia for all macronutrients tested except butyric acid, where mRNA transcript levels were significantly increased compared to ambient $\mathrm{O}_{2}(\mathrm{P}<0.05)$ (Fig. 1B). Treatment of STC-1 cells with glucose, tripeptide, butyric and oleic acids increased production of GLP-1 compared to the control in hypoxia, while no effect of treatments was observed in normoxia. This absence of correlation between production and secretion of active GLP-1 hormone suggests that regulation of its secretion in hypoxia occurs at post-transcriptional level. For instance other products of proglucagon, such as oxyntomodulin, GLP-2 and GLP-1 (1-37) may be released and the ratio of total to active GLP-1 (737) may differ [6]. Indeed, the significant stimulatory effect of casein could be a result of the release of active GLP-1 from secretory granules, without changes in the gene expression level. Kihiria et al. reported that hypoxia conditions reduced proglucagon mRNA transcript level in GLUTag cells but these observations were in response to cAMP stimulator Fsk in the presence of $2.5 \mathrm{mM}$ glucose [19]. Similarly, levels of $P Y Y$ and $C C K$ mRNA transcripts were not significantly different $(\mathrm{P}>0.05)$ in 
hypoxic conditions compared to ambient $\mathrm{O}_{2}$ for each of the test food components except for butyric acid (1.86 and 1.82 vs. 1.42 and 1.39 fold change hypoxia versus ambient $\mathrm{O}_{2}$ ).

Secretion of GLP-1 by pGIP/Neo STC-1 and their viability in the presence of $0-10 \mathrm{mg} / \mathrm{mL}$ of whole casein, casein proteins and their hydrolysates were studied before [42]. How the cells survive and proliferate in hypoxia for 4 hours in the presence of casein and other food components was measured by CellTox ${ }^{\mathrm{TM}}$ cytotoxicity assay and Cell Titter cell proliferation assay. STC-1 cell line prefers the hypoxic environment with remarkably higher viability $(\mathrm{P}<0.01)$ at $0.5 \% \mathrm{O}_{2}$ than at $20 \% \mathrm{O}_{2}$ for all treatments against a backdrop of modified Krebs-Ringer buffer (Fig. 2A). At the same time, cytotoxicity was comparable between ambient $\mathrm{O}_{2}$ and hypoxic conditions with significant differences $(\mathrm{P}<0.05)$ only observed for the treatments with glucose and casein (Fig. 2B). Only treatment with casein in normoxia was able to improve cell viability compared to the control. This combined result indicates that, not surprisingly, the STC-1 cell line derived from the small intestine prefers hypoxia conditions. We would therefore suggest the use of hypoxic conditions for future studies where complex media is unsuitable [5].

\subsection{GLP-1 secretion over a range of oxygen concentrations}

$\mathrm{O}_{2}$ concentration in the gastro-intestinal epithelium decreases distally, with reports of $7.5 \%$ in the stomach, $4.5 \%$ in the duodenum, $1.5 \%$ in the colon and small intestine and $0.5 \%$ in the colon-rectal junction of mice [12]. To study if GLP-1 release linearly depends on the $\mathrm{O}_{2}$ concentration, STC-1 cells were exposed to $\mathrm{O}_{2}$ levels resembling physiological conditions of the GI tract. As casein significantly increased active GLP-1 release above vehicle control and resulted in a large difference between hypoxic and ambient conditions, it was chosen to evaluate GLP-1 release at various concentrations of oxygen (Fig. 3A). Secreted GLP-1 levels in response to intact casein depend on $\mathrm{O}_{2}$ concentration, with an inverted bell curve response. The highest GLP-1 levels were observed at 20\% $\mathrm{O}_{2}(9.15+/-0.03 \mathrm{ng} / \mathrm{mL})$ and the lowest levels at $7.5 \% \mathrm{O}_{2}(2.58+/-0.04 \mathrm{ng} / \mathrm{mL})$ with hypoxic conditions resulting in $6.27+/-0.15 \mathrm{ng} / \mathrm{mL}$. Interestingly the GLP-1 levels in response to $11 \mathrm{mM}$ 
glucose (control) varied from 0.58 to $1.49 \mathrm{ng} / \mathrm{mL}$ and were significantly higher at $7.5 \%$ and $20 \% \mathrm{O}_{2}$ than at $0.5 \%$ and $1.5 \% \mathrm{O}_{2}$.

\subsection{Mechanism of hypoxia influence on GLP-1 production.}

In vivo, enteroendocrine cells sense (a) amino acids and proteins via taste receptors T1R1/T1R3 and pept1/pept2 channels [8], (b) fatty acids via GPCRs [7] and (c) carbohydrates via sweet taste receptors T1R2/T1R3 and transporters GLUT1 or GLUT5 [43]. Such interactions lead to electrogenic $\left(\mathrm{Ca}^{2+}\right.$ flux) and electroneutral (cAMP) governed release of GLP-1. Figure 3B details cAMP and intracellular $\mathrm{Ca}^{2+}$ levels in STC-1 cells, exposed for 4 hours to $10 \mathrm{mg} / \mathrm{mL}$ casein and modified Krebs-Ringer buffer as a control. Intracellular cAMP levels are significantly lower $(\mathrm{P}<0.05)$ in response to intact casein under hypoxic conditions compared to normoxic conditions ( 8.65 and $10.92 \mathrm{pmol} / \mathrm{mL}$ respectively). Interestingly, the ability of STC-1 cells to increase cAMP levels in response to the cAMP stimulator Fsk is significantly attenuated under hypoxia $(60.7 \mathrm{pmol} / \mathrm{mL}$ in hypoxia vs. $146.3 \mathrm{pmol} / \mathrm{mL}$ cAMP in normoxia). This is in good agreement with Kihara et al. who observed a 2 fold decrease in ATP levels when GLUTag cells were exposed to Fsk under hypoxia [19]. In STC-1 cells $\mathrm{Ca}^{2+}$ levels in response to casein are not influenced by hypoxia (Fig. 3B). In contrast, intracellular $\mathrm{Ca}^{2+}$ levels rise in pulmonary arterial myocytes and in rat neonatal carotid body type I cells in response to hypoxia via generation of mitochondrial reactive oxygen species (ROS) [44, 45]. The reduction in GLP-1 exocytosis in response to intact casein in hypoxic conditions may therefore be a symptom of the dampening of the cAMP signalling pathway rather than $\mathrm{Ca}^{2+}$ involvement.

\subsection{Food digestion in study of gut hormone regulation}

To study the effect of physiological $\mathrm{O}_{2}$ concentrations together with different phases of food digestion on enteroendocrine secretion of active GLP-1, commercially available yogurt (2.8 g fat, $5.6 \mathrm{~g}$ carbohydrates, $5.2 \mathrm{~g}$ protein per $100 \mathrm{~g}$ ) was subjected to oral, gastric and intestinal SGID [46]. STC-1 cells were then incubated at $7.5 \% \mathrm{O}_{2}$ to represent typical conditions for orally digested food, $4.5 \% \mathrm{O}_{2}$ for gastric and $1.5 \% \mathrm{O}_{2}$ for intestinal digestas. Secreted GLP-1 levels in response to yogurt digestas 
compared to whole yogurt are detailed in Figure 4A. GLP-1 levels secreted in response to oral, gastric and intestinal yogurt digestas at their matching $\mathrm{O}_{2}$ concentrations ranged from 4.41 to $21.62 \mathrm{ng} / \mathrm{mL}$, with levels for gastric yogurt digesta at $4.5 \% \mathrm{O}_{2}$ significantly higher than for either oral or intestinal digesta samples $(\mathrm{P}<0.05)$. In contrast, GLP-1 levels secreted in response to whole yogurt at different $\mathrm{O}_{2}$ concentrations had a narrower range from 6.47 to $8.08 \mathrm{ng} / \mathrm{mL}$. Interestingly, STC-1 cells exposed to intestinal yogurt digesta at $1.5 \% \mathrm{O}_{2}$ secreted significantly lower levels $(\mathrm{P}<0.05)$ of GLP-1 than any of the other test samples including whole yogurt. GLP-1 levels in response to yogurt digesta at each SGID stage with corresponding $\mathrm{O}_{2}$ concentration were significantly different $(\mathrm{P}<0.05)$ compared to levels with yogurt at $20 \% \mathrm{O}_{2}$ (shown with dashed line).

The density of $\mathrm{L}$ cells increases from duodenum to colon, as $\mathrm{O}_{2}$ concentration decreases [11]. Theoretically predicted efficiency of GLP-1 production was calculated from the GLP-1 levels obtained at each physiological condition (Figs. 3A, 4A) as a function of the predicted number of cells at each location within the GI tract $[10,11]$. Limitations of this theoretical model include the use of STC-1 cell monolayer versus heterogeneous 3D structure of the GI tract and the difficulty to predict sensitivity of L cells to treatment and absorption of nutrients at different locations of GI tract. However, the model benefits from including $\mathrm{O}_{2}$ concentration and the stage of food digestion as factors, influencing GLP-1 secretion. This model predicts that yogurt digesta would be a more potent stimulant of GLP-1 secretion than glucose in the gut and peak levels of secreted GLP-1 would occur in the ileal and colon (Fig 4B).

\section{Concluding Remarks}

In conclusion, intact casein can increase levels of GLP-1 secretion from glucose- stimulated STC-1 cells, probably via intracellular $\mathrm{Ca}^{2+}$ signalling. At low oxygen concentrations this secretion is attenuated possibly by a decrease in cAMP levels. Exposing enteroendocrine STC-1 cells to oxygen concentrations and food digesta relevant to specific GI locations significantly alters the level of active GLP-1 secreted. As yogurt transits the gut, 4.5\% oxygen and digesta of the gastric phase generate peak GLP-1 levels. Transcription of satiety hormones is not affected by hypoxia for variety of 
stimulations with macronutrients except for butyric acid, which is produced by the bacteria of the hypoxic colon. Where cells are assayed in buffers, cell viability is an issue and can be improved by the use of hypoxic conditions. Altogether, physiological $\mathrm{O}_{2}$ levels and food digestion have significant influence on gut hormone secretion and their impacts on satiety hormones warrant further investigation.

Author Contributions: A.K. and L.G. designed the experiments. A.K. carried out practical work. D.P. provided expertise in hypoxic conditions. A.K. and L.G. wrote the manuscript, D.P. revised the manuscript.

Acknowledgements: This work was funded by Enterprise Ireland under Grant Number TC20130001. We would like to thank Paula O'Connor for synthesis of tripeptide. We would like to thank Tom Beresford for his assistance in the acquisition of funding.

Conflict of Interest: The authors have declared no conflicts of interest.

\section{References}

[1] Spreckley, E., Murphy, K. G., The L-cell in nutritional sensing and the regulation of appetite. Frontiers in nutrition 2015, 2, 23.

[2] Zhou, J., Hegsted, M., McCutcheon, K. L., Keenan, M. J., Xi, X., Raggio, A. M., Martin, R. J., Peptide $Y Y$ and proglucagon mRNA expression patterns and regulation in the gut. Obesity 2006, 14, 683-689.

[3] Reimann, F., Gribble, F. M., Mechanisms underlying glucose-dependent insulinotropic polypeptide and glucagon-like peptide-1 secretion. Journal of diabetes investigation 2016, 7, 13-19. [4] Liou, J., Kim, M. L., Do Heo, W., Jones, J. T., Myers, J. W., Ferrell, J. E., STIM is a $\mathrm{Ca}^{2+}$ sensor essential for $\mathrm{Ca}^{2+}$-store-depletion-triggered $\mathrm{Ca}^{2+}$ influx. Current Biology 2005, 15, 1235-1241. 
[5] McCarthy, T., Green, B. D., Calderwood, D., Gillespie, A., Cryan, J. F., Giblin, L., The Impact of Food Bioactives on Health, Springer 2015, pp. 211-220.

[6] Tolhurst, G., Reimann, F., Gribble, F. M., Nutritional regulation of glucagon-like peptide-1 secretion. The Journal of physiology 2009, 587, 27-32.

[7] Tolhurst, G., Heffron, H., Lam, Y. S., Parker, H. E., Habib, A. M., Diakogiannaki, E., Cameron, J., Grosse, J., Reimann, F., Gribble, F. M., Short-chain fatty acids stimulate glucagon-like peptide-1 secretion via the G-protein-coupled receptor FFAR2. Diabetes 2012, 61, 364-371.

[8] Tolhurst, G., Reimann, F., Gribble, F. M., Appetite Control, Springer 2012, pp. 309-335.

[9] Tian, L., Jin, T., The incretin hormone GLP-1 and mechanisms underlying its secretion. Journal of diabetes 2016, 8, 753-765.

[10] Gunawardene, A. R., Corfe, B. M., Staton, C. A., Classification and functions of enteroendocrine cells of the lower gastrointestinal tract. International journal of experimental pathology 2011, 92, 219-231.

[11] Sjolund, K., Sanden, G., Hakanson, R., Sundler, F., Endocrine cells in human intestine: an immunocytochemical study. Gastroenterology 1983, 85, 1120-1130.

[12] He, G., Shankar, R. A., Chzhan, M., Samouilov, A., Kuppusamy, P., Zweier, J.L., Noninvasive measurement of anatomic structure and intraluminal oxygenation in the gastrointestinal tract of living mice with spatial and spectral EPR imaging. Proceedings of the National Academy of Sciences 1999, 96, 4586-4591.

[13] Zheng, L., Kelly, C. J., Colgan, S. P., Physiologic hypoxia and oxygen homeostasis in the healthy intestine. A review in the theme: cellular responses to hypoxia. American Journal of Physiology-Cell Physiology 2015, 309, C350-C360.

[14] Wang, X., Liu, H., Chen, J., Li, Y., Qu, S., Multiple factors related to the secretion of glucagonlike peptide-1. International journal of endocrinology 2015, 2015.

[15] Ratcliffe, P. J., Oxygen sensing and hypoxia signalling pathways in animals: the implications of physiology for cancer. The Journal of physiology 2013, 591, 2027-2042. 
[16] Denko, N. C., Hypoxia, HIF1 and glucose metabolism in the solid tumour. Nature Reviews Cancer 2008, 8, 705-713.

[17] Papkovsky, D. B., Zhdanov, A. V., Phosphorescence based $\mathrm{O}_{2}$ sensors-Essential tools for monitoring cell and tissue oxygenation and its impact on metabolism. Free Radical Biology and Medicine 2016, 101, 202-210.

[18] Trayhurn, P., Hypoxia and adipose tissue function and dysfunction in obesity. Physiological reviews 2013, 93, 1-21.

[19] Kihira, Y., Burentogtokh, A., Itoh, M., Izawa-Ishizawa, Y., Ishizawa, K., Ikeda, Y., Tsuchiya, K., Tamaki, T., Hypoxia Decreases Glucagon-Like Peptide-1 Secretion from the GLUTag Cell Line. Biological and Pharmaceutical Bulletin 2015, 38, 514-521.

[20] Rindi, G., Grant, S., Yiangou, Y., Ghatei, M. A., Bloom, S. R., Bautch, V. L., Solcia, E., Polak, J. M., Development of neuroendocrine tumors in the gastrointestinal tract of transgenic mice. Heterogeneity of hormone expression. The American journal of pathology 1990, 136, 1349.

[21] Drucker, D. J., Jin, T., Asa, S. L., Young, T. A., Brubaker, P. L., Activation of proglucagon gene transcription by protein kinase-A in a novel mouse enteroendocrine cell line. Molecular Endocrinology 1994, 8, 1646-1655.

[22] Park, J.-G., Oie, H. K., Sugarbaker, P. H., Henslee, J. G., Chen, T.-R., Johnson, B. E., Gazdar, A., Characteristics of cell lines established from human colorectal carcinoma. Cancer research 1987, $47,6710-6718$.

[23] Kuhre, R. E., Albrechtsen, N. J. W., Deacon, C. F., Balk-Møller, E., Rehfeld, J. F., Reimann, F., Gribble, F. M., Holst, J. J., Peptide production and secretion in GLUTag, NCI-H716, and STC-1 cells: a comparison to native L-cells. Journal of molecular endocrinology 2016, 56, 201-211.

[24] Kuhre, R. E., Albrechtsen, N. W., Windeløv, J. A., Svendsen, B., Hartmann, B., Holst, J. J., GLP-1 amidation efficiency along the length of the intestine in mice, rats and pigs and in GLP-1 secreting cell lines. Peptides 2014, 55, 52-57.

[25] Aziz, A., Anderson, G., Saarela, M., The effects of dairy components on food intake and satiety. Functional dairy products 2007, 2, 19-45. 
[26] Dougkas, A., Reynolds, C. K., Givens, I. D., Elwood, P. C., Minihane, A. M., Associations between dairy consumption and body weight: a review of the evidence and underlying mechanisms. Nutrition research reviews 2011, 24, 72-95.

[27] Bendtsen, L. Q., Lorenzen, J. K., Bendsen, N. T., Rasmussen, C., Astrup, A., Effect of dairy proteins on appetite, energy expenditure, body weight, and composition: a review of the evidence from controlled clinical trials. Advances in Nutrition: An International Review Journal 2013, 4, 418438.

[28] Dougkas, A., Minihane, A. M., Givens, D. I., Reynolds, C. K., Yaqoob, P., Differential effects of dairy snacks on appetite, but not overall energy intake. British Journal of Nutrition 2012, 108, 22742285.

[29] Ruijschop, R. M., Boelrijk, A. E., te Giffel, M. C., Satiety effects of a dairy beverage fermented with propionic acid bacteria. International Dairy Journal 2008, 18, 945-950.

[30] Hall, W., Millward, D., Long, S., Morgan, L., Casein and whey exert different effects on plasma amino acid profiles, gastrointestinal hormone secretion and appetite. British Journal of Nutrition 2003, 89, 239-248.

[31] Chen, Q., Reimer, R. A., Dairy protein and leucine alter GLP-1 release and mRNA of genes involved in intestinal lipid metabolism in vitro. Nutrition 2009, 25, 340-349.

[32] Bruen, C. M., Kett, A. P., O'Halloran, F., Chaurin, V., Fenelon, M. A., Cashman, K. A., Giblin, L., Effect of gelatinisation of starch with casein proteins on incretin hormones and glucose transporters in vitro. The British journal of nutrition 2012, 107, 155-163.

[33] Bohl, M., Bjornshave, A., Rasmussen, K. V., Schioldan, A. G., Amer, B., Larsen, M. K., Dalsgaard, T. K., Holst, J. J., Herrmann, A., O'Neill, S., O’Driscoll, L., Afman, L., Jensen, E., Christensen, M. M., Gregersen, S., Hermansen, K., Dairy proteins, dairy lipids, and postprandial lipemia in persons with abdominal obesity (DairyHealth): a 12-wk, randomized, parallel-controlled, double-blinded, diet intervention study. The American journal of clinical nutrition 2015, 101, 870878.

[34] Månsson, H. L., Fatty acids in bovine milk fat. Food \& nutrition research 2008, 52. 
[35] Iakoubov, R., Izzo, A., Yeung, A., Whiteside, C. I., Brubaker, P. L., Protein Kinase Cל Is Required for Oleic Acid-Induced Secretion of Glucagon-Like Peptide-1 by Intestinal Endocrine L Cells. Endocrinology 2007, 148, 1089-1098.

[36] Adam, T., Westerterp-Plantenga, M., Nutrient-stimulated GLP-1 release in normal-weight men and women. Hormone and Metabolic Research 2005, 37, 111-117.

[37] Dmitriev, R. I., Papkovsky, D. B., In vitro ischemia decreases histone H4K16 acetylation in neural cells. FEBS letters 2015, 589, 138-144.

[38] Yadav, H., Lee, J.-H., Lloyd, J., Walter, P., Rane, S. G., Beneficial metabolic effects of a probiotic via butyrate-induced GLP-1 hormone secretion. Journal of Biological Chemistry 2013, 288, 25088-25097.

[39] Hand, K. V., Bruen, C. M., O'Halloran, F., Giblin, L., Green, B. D., Acute and chronic effects of dietary fatty acids on cholecystokinin expression, storage and secretion in enteroendocrine STC-1 cells. Molecular nutrition \& food research 2010, 54, S93-S103.

[40] Geraedts, M. C., Troost, F. J., Fischer, M. A., Edens, L., Saris, W. H., Direct induction of CCK and GLP-1 release from murine endocrine cells by intact dietary proteins. Molecular nutrition $\&$ food research 2011, 55, 476-484.

[41] Gribble, F. M., Williams, L., Simpson, A. K., Reimann, F., A novel glucose-sensing mechanism contributing to glucagon-like peptide-1 secretion from the GLUTag cell line. Diabetes 2003, 52, $1147-1154$.

[42] Gillespie, A. L., Green, B. D., The bioactive effects of casein proteins on enteroendocrine cell health, proliferation and incretin hormone secretion. Food chemistry 2016, 211, 148-159.

[43] Jang, H.-J., Kokrashvili, Z., Theodorakis, M. J., Carlson, O. D., Kim, B.-J., Zhou, J., Kim, H. H., Xu, X., Chan, S. L., Juhaszova, M., Bernier, M., Mosinger, B., Margolskee, R. F., Egan, J. M., Gutexpressed gustducin and taste receptors regulate secretion of glucagon-like peptide-1. Proceedings of the National Academy of Sciences 2007, 104, 15069-15074. 
[44] Waypa, G. B., Marks, J. D., Mack, M. M., Boriboun, C., Mungai, P. T., Schumacker, P. T., Mitochondrial reactive oxygen species trigger calcium increases during hypoxia in pulmonary arterial myocytes. Circulation research 2002, 91, 719-726.

[45] Buckler, K., Vaughan-Jones, R., Effects of hypoxia on membrane potential and intracellular calcium in rat neonatal carotid body type I cells. The Journal of Physiology 1994, 476, 423.

[46] Minekus, M., Alminger, M., Alvito, P., Ballance, S., Bohn, T., Bourlieu, C., Carrière, F., Boutrou, R., Corredig, M., Dupont, D., Dufour, C., Egger, L., Golding, M., Karakaya, S., Kirkhus, B., Feunteun, S. L., Lesmes, U., Macierzanka, A., Mackie, A., Marze, S., McClements, D. J., Ménard, O., Recio, I., Santos, C. N., Singh, R. P., Vegarud, G. E., Wickham, M. S. J., Weitschies, W., Brodkorb, A., A standardised static in vitro digestion method suitable for food - an international consensus. Food \& function 2014, 5, 1113-1124. 
Figure 1. GLP-1 production and secretion in STC-1 cells exposed to different macronutrients at atmospheric normoxia $\left(20 \% \mathrm{O}_{2}\right)$ and hypoxia $\left(0.5 \% \mathrm{O}_{2}\right)$. STC-1 cells were exposed to negative control (modified Krebs-Ringer), $40 \mathrm{mM}$ glucose, $40 \mathrm{mM}$ lactose, $100 \mu \mathrm{M}$ butyric acid, $100 \mu \mathrm{M}$ oleic acid, $0.5 \mathrm{mg} / \mathrm{mL}$ tripeptide or $10 \mathrm{mg} / \mathrm{mL}$ casein for 4 hours. A. Levels of secreted GLP-1 (active) in STC-1 cell supernatants. B. Levels of proglucagon mRNA transcripts in STC-1 cell lysates. ActB was used as a reference gene. Asterisks indicate significant differences for each food component between normoxic and hypoxic conditions $(\mathrm{P}<0.05)$. Number signs indicate significant differences for each $\mathrm{O}_{2}$ concentration between control and treatment $(\mathrm{P}<0.05)$.

A

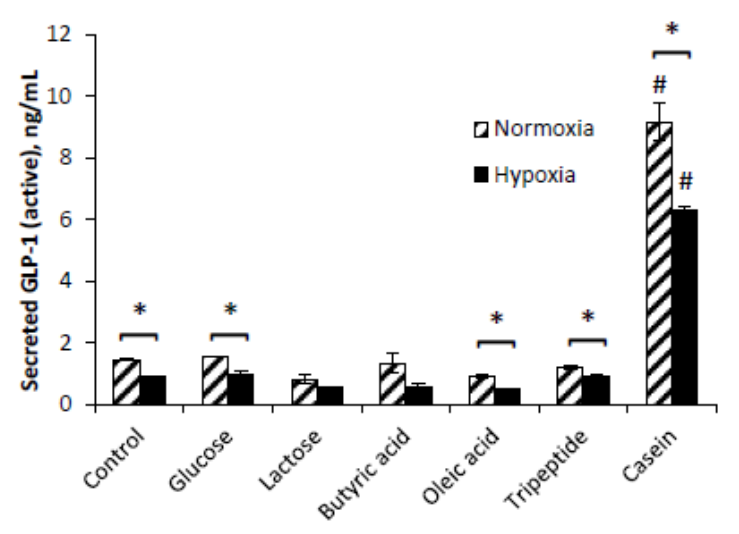

\section{B}

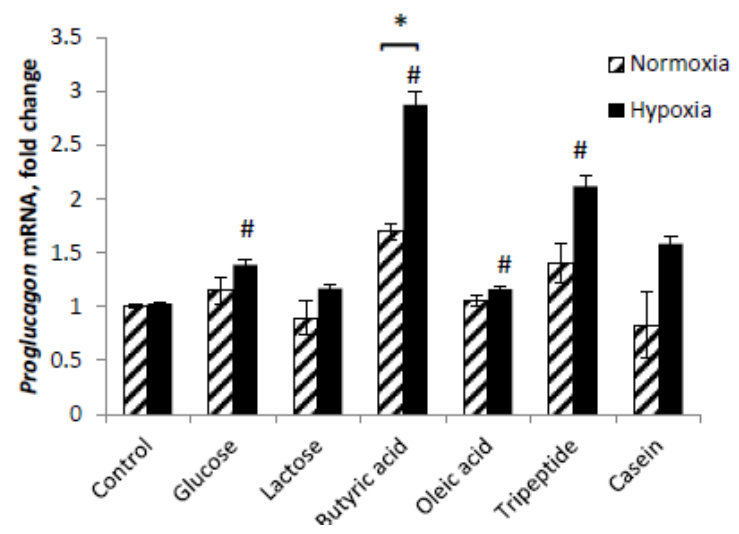


Figure 2. Effect of $\mathrm{O}_{2}$ concentration on STC-1 cell viability and toxicity after 4 hours of exposure to different macronutrients at atmospheric normoxia $\left(20 \% \mathrm{O}_{2}\right)$ and hypoxia $(0.5 \%$ $\mathbf{O}_{2}$ ). STC-1 cells were exposed to negative control (modified Krebs-Ringer), $40 \mathrm{mM}$ glucose, $40 \mathrm{mM}$ lactose, $100 \mu \mathrm{M}$ butyric acid, $100 \mu \mathrm{M}$ oleic acid, $0.5 \mathrm{mg} / \mathrm{mL}$ tripeptide or $10 \mathrm{mg} / \mathrm{mL}$ casein for 4 hours. A. STC-1 cell viability is presented as percentage, where exposure to DMEM at $20 \% \mathrm{O}_{2}$ represents $100 \%$ cell viability. B. STC-1 cell toxicity is presented as percentage, where cell lysate at normoxia represents $100 \%$ cytotoxicity. Asterisks indicate significant differences for each food component between normoxic and hypoxic conditions $(* \mathrm{P}<0.05$, $* * \mathrm{P}<0.01)$. Number signs indicate significant differences for each $\mathrm{O}_{2}$ concentration between control and treatment $(\mathrm{P}<0.05)$.

A

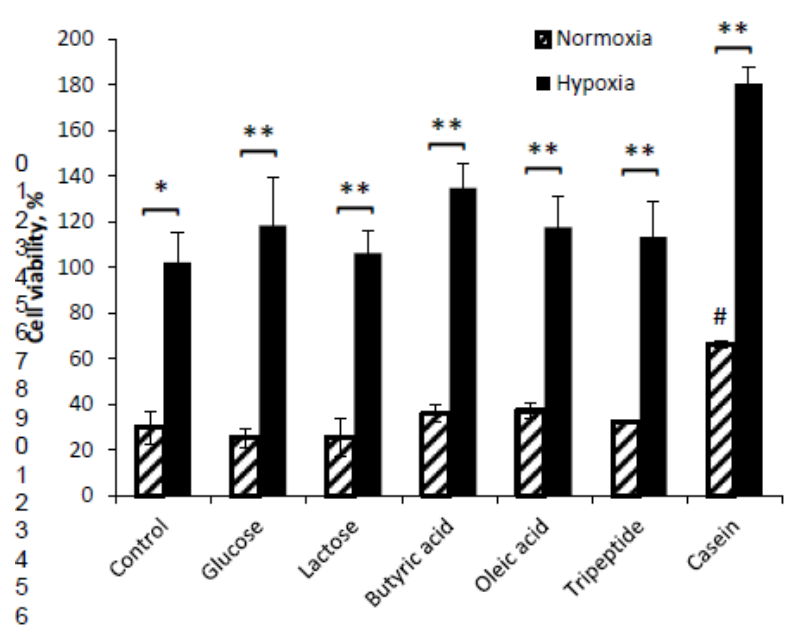

B

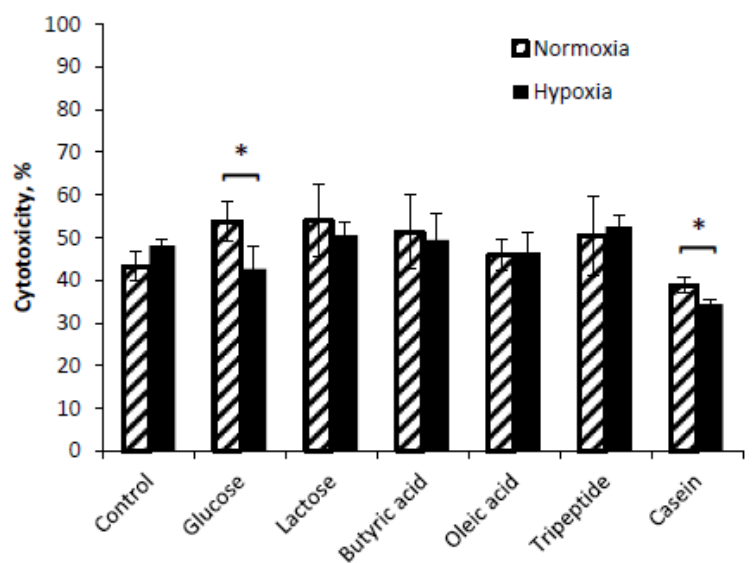


Figure 3 A. Secretion of active GLP-1 from STC-1 cells at various $O_{2}$ concentrations, corresponding to the different parts of GI tract. STC-1 cells were exposed to negative control (modified Krebs-Ringer) or $10 \mathrm{mg} / \mathrm{mL}$ casein at $0.5,1.5,4.5,7.5$ and $20 \% \mathrm{O}_{2}$ for 4 hours. Different superscript letters (generated with One way ANOVA test) indicate significant difference in active GLP-1 $(\mathrm{P}<0.05)$ at different oxygenation for a treatment. B. Effects of $\mathbf{O}_{2}$ on GLP-1 secretion pathways. STC-1 cells were exposed to control (supplemented with $1 \mathrm{mM}$ IBMX modified KrebsRinger buffer) or $10 \mathrm{mg} / \mathrm{mL}$ casein. Intracellular cAMP and $\mathrm{Ca}^{2+}$ levels in STC-1 cells were measured after 4 hours exposure. Results of cAMP assay were generated at optical density of $405 \mathrm{~nm}$. For $\mathrm{Ca}^{2+}$ assay fluorescence signals were collected with excitation $488 \mathrm{~nm}$ and emission $520 \mathrm{~nm}$ and presented as relative to control (modified Krebs-Ringer at $20 \% \mathrm{O}_{2}$ ). Asterisks indicate significant differences between normoxic and hypoxic conditions $(\mathrm{P}<0.05)$. 

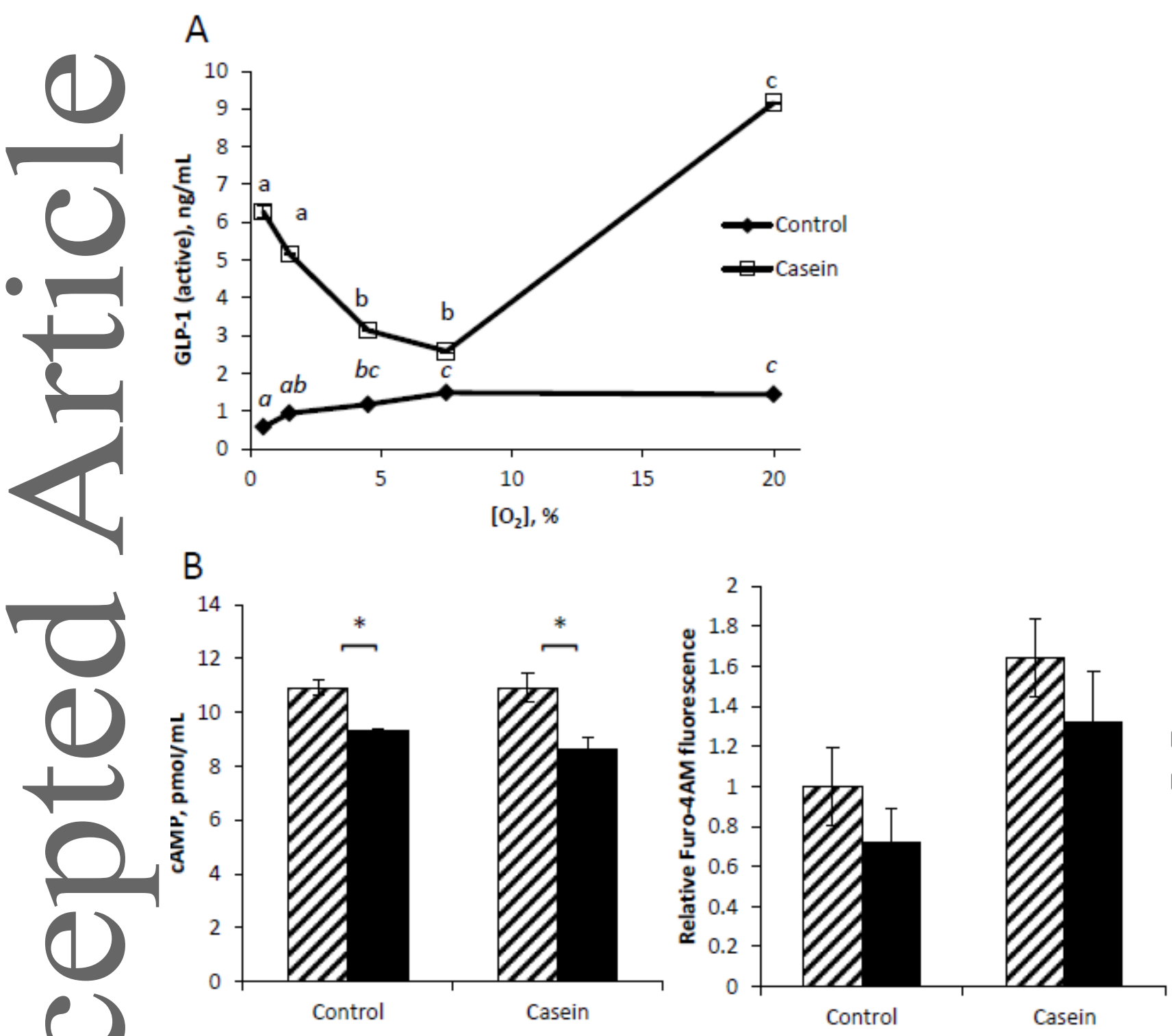

Normoxia

- Hypoxia

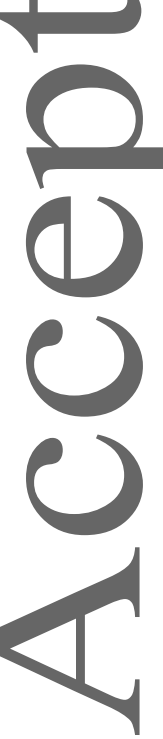

This article is protected by copyright. All rights reserved. 
Figure 4. A. Effect of food digestion and $\mathrm{O}_{2}$ concentration on active GLP-1 secretion from STC-1 cells. STC-1 cells were exposed to commercial yogurt, at different phases of SGID (oral, gastric and intestinal) with physiologically relevant $\mathrm{O}_{2}$ concentrations. Specifically, cells were treated with yogurt orally digested at $7.5 \%$, gastrically digested - at $4.5 \%$ and intestinally digested - at $1.5 \% \mathrm{O}_{2}$. Cells were exposed to modified Krebs-Ringer buffer as negative control and whole yogurt for comparison purposes. Level of GLP-1 secretion after exposure to yogurt at $20 \% \mathrm{O}_{2}$ is shown with dashed line. $\mathbf{B}$. Predicted efficiency of GLP-1 secretion at different parts of GI tract. Predicted GLP-1 secretion = [GLP-1] ${ }^{*}\left(\mathrm{~N}_{\mathrm{GI}} / \mathrm{N}_{\mathrm{w}}\right)$ where [GLP-1] is concentration of active GLP-1 secreted by STC-1 in response to stimulation, $\mathrm{N}_{\mathrm{w}}$ - number of STC-1 cells in the well and $\mathrm{N}_{\mathrm{GI}}$ - predicted number of $\mathrm{L}$ cells in the corresponding part of GI tract [11]. Different superscript letters (generated with One way ANOVA test) indicate significant difference $(\mathrm{P}<0.05)$ in active GLP-1 secretion within an $\mathrm{O}_{2}$ concentration. Asterisks indicate significant differences for each treatment between normoxic and hypoxic conditions $(* \mathrm{P}<0.05, * * \mathrm{P}<0.01)$.

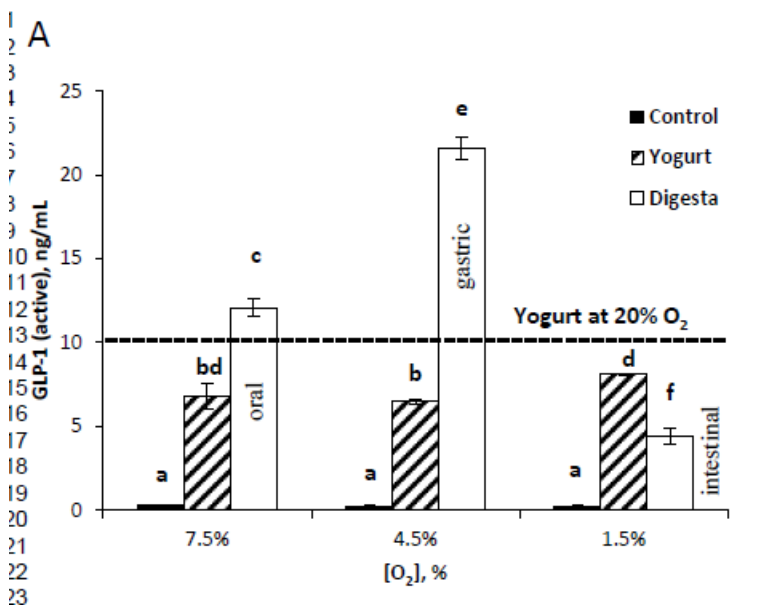

B

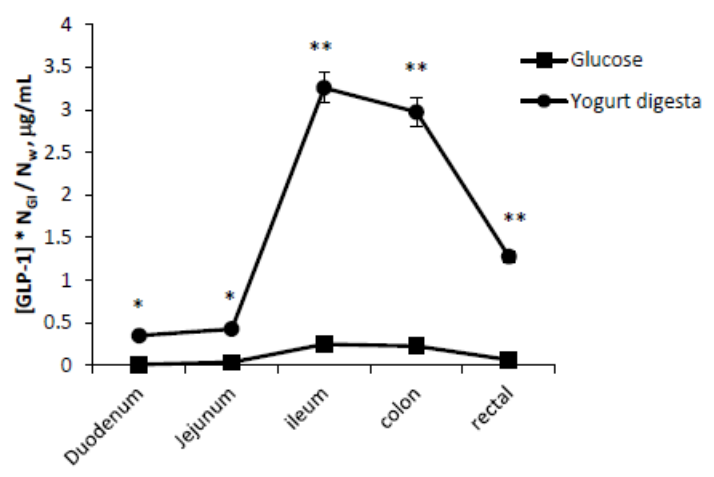




\section{Graphic Abstract}

Secretion of hormones in the gut is accompanied by food digestion, decreasing oxygen concentration and increasing number of $\mathrm{L}$ cells towards the distal gut. These parameters are missing in exisiting in vitro models and their effects on study outcomes are not estimated. In this paper we report on the significant influence of low oxygen and food digestion on secretion of satiety hormone GLP-1 from enteroendocrine STC-1 cells.

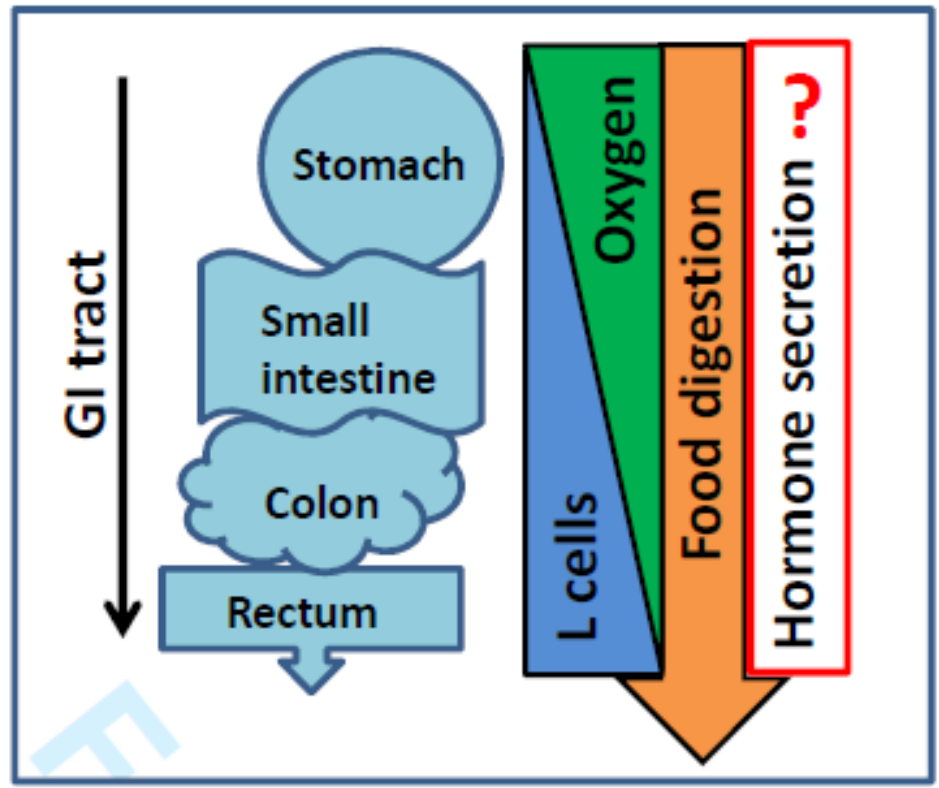

